\title{
PENGARUH INFLASI, PDB, INVESTASI DAN PENDIDIKAN TERHADAP TINGKAT PENGANGGURAN DI INDONESIA PERIODE TAHUN 1999-2015
}

\author{
Eef Saefulloh dan Renjana Fitriana \\ Fakultas Syari'ah dan Ekonomi Islam \\ Institut Agama Islam Negeri Syekh Nurjati Cirebon \\ email: eefsae2003@gmail.com dan renjana90@yahoo.com
}

\begin{abstract}
Generally, the unemployment is affected by the amount of applicants or the amount of applicants are not same with the total of field-work that needs employees. Many factors affect the level of unemployment $(Y)$, inflation $\left(X_{1}\right), G N P\left(X_{2}\right)$, Investation $\left(X_{3}\right)$, and education $\left(X_{4}\right)$ which were developed by the dummy variables to $S D / M I\left(D_{1}\right)$, SMP/MTs $\left(D_{2}\right), S M A / M A\left(D_{3}\right)$ and than $P T\left(D_{4}\right)$. According of the result of analyzing the data and hypothesis, the result got $F_{\text {count }} 17,59>F_{\text {tabel }} 3.26$, thus independently simultaneous free affected significantly to the level of unemployment in Indonesia. The result of T-test, the free varibales influenced in the level of unemployment in Indonesia, with each results: variables of inflation $\left(X_{1}\right) T_{\text {count }} 3,317$ $>T_{\text {tabel }} 1,833, G N P\left(X_{2}\right) T_{\text {count }}-4,788>T_{\text {tabel }} 1,833$, investation $\left(X_{3}\right) T_{\text {count }}-2,396>T_{\text {tabel }}$ 1,833, and education with dummy variable $S D / M I\left(D_{1}\right) T_{\text {count }}-4,542>T_{\text {tabel }} 1,833$, $S M P / M T s\left(D_{2}\right) T_{\text {count }} 9,305>T_{\text {tabel }} 1,833$, SMA/MA (D $\left.D_{3}\right) T_{\text {count }}-4,373>T_{\text {tabel }} 1,833$, and but on the dummy variables college level there is no influence on the unemployment rate where the value $P T\left(D_{4}\right) T_{\text {count }}-0,183>T_{\text {tabel }} 1,833$.
\end{abstract}

Keywords: Inflation, GNP, Investation, Education and The Level of Unemployment.

\begin{abstract}
Abstrak
Pengangguran pada umumnya disebabkan karena jumlah angkatan kerja atau jumlah pencari kerja tidak sebanding dengan jumlah lapangan kerja yang ada mampu menyerapnya. Adapun faktor-faktor yang mempengaruhi tingkat pengangguran $(Y)$, inflasi $\left(X_{1}\right), \operatorname{PDB}\left(X_{2}\right)$, Investasi $\left(X_{3}\right)$, dan pendidikan $\left(X_{4}\right)$ yang dikembangkan dengan variabel dummy terhadap SD/MI $\left(D_{1}\right)$, SMP/MTs $\left(D_{2}\right), S M A / M A\left(D_{3}\right)$ serta PT $\left(D_{4}\right)$. Berdasarkan hasil analisis dan pengujian hipotesis diperoleh $F_{\text {hitung }} 17,593>F_{\text {tabel }} 3.26$, sehingga secara simultan variabel bebas berpengaruh signifikan terhadap tingkat pengangguran di Indonesia. Sedangkan hasil uji $T$ secara serentak variabel bebas berpengaruh terhadap tingkat pengangguran dengan nilai masing-masing, variabel inflasi $\left(X_{1}\right) T_{\text {hitung }} 3,317>T_{\text {tabel }} 1,833, P D B\left(X_{2}\right) T_{\text {hitung }}-4,788>$ $T_{\text {tabel }} 1,833$, Investasi $\left(X_{3}\right) T_{\text {hitung }}-2,396>T_{\text {tabel }} 1,833$, dan pendidikan dengan variabel dummy SD/MI $\left(D_{1}\right) T_{\text {hitung }}-4,542>T_{\text {tabel }} 1,833$, SMP/MTs $\left(D_{2}\right) T_{\text {hitung }} 9,305>T_{\text {tabel }} 1,833$, $S M A / M A\left(D_{3}\right) T_{\text {hitung }}-4,373>T_{\text {tabel }} 1,833$, namun pada variabel dummy tingkat perguruan tinggi tidak terdapat pengaruh terhadap tingkat pengangguran dimana nilai $P T\left(D_{4}\right) T_{\text {hitung - }}$ $0,183<T_{\text {tabel }} 1,833$.
\end{abstract}

Kata Kunci: Inflasi, PDB, Investasi, Pendidikan dan Tingkat Pengangguran. 


\section{PENDAHULUAN}

Keberhasilan suatu negara dapat dilihat dari pertumbuhan ekonominya, oleh karena itu banyak faktor-faktor yang dapat mempengaruhi pertumbuhan ekonomi suatu negara. Masalah yang terus menerus menjadi perhatian negara Indonesia adalah masalah pengangguran. Pengangguran adalah seseorang atau sekelompok orang yang termasuk angkatan kerja yang tidak dapat bekerja dan sedang mencari pekerjaan menurut referensi tertentu. ${ }^{1}$

Tingkat pengangguran merupakan hal yang sangat mempengaruhi pertumbuhan ekonomi di suatu negara. Dalam pembangunan ekonomi di negara berkembang pengangguran yang semakin bertambah jumlahnya merupakan masalah yang lebih rumit dan lebih serius dari masalah perubahan dalam distribusi pendapatan yang kurang menguntungkan penduduk yang berpendapatan rendah. Keadaan di negara berkembang dalam beberapa dasawarsa ini menunjukan bahwa pembangunan ekonomi tidak sanggup menciptakan kesempatan kerja yang lebih cepat dari pertambahan penduduk. Oleh karenanya, masalah pengangguran yang dihadapi dari tahun ketahun semakin lama semakin bertambah serius. ${ }^{2}$

Indonesia merupakan negara dengan jumlah penduduk yang sangat banyak serta memiliki sumber kekayaan alam yang melimpah, hal ini membuat Indonesia pantas disebut sebagai negara yang kaya akan sumber dayanya, baik sumber daya manusia maupun sumber daya alam. Namun faktanya, banyak warga negara Indonesia yang tidak memiliki pekerjaan, dan menjadi pengangguran di negaranya sendiri. Tingkat kelahiran di Indonesia tidak dibarengi dengan banyaknya lapangan kerja yang

${ }^{1}$ Nur Feriyanto, Ekonomi Sumber Daya Manusia Dalam Perspektif Indonesia (Yogyakarta: UPP STIM YKPN, 2014), 159.

${ }^{2}$ Sadono Sukirno, Ekonomi Pembangunan: Proses, Masalah, dan Dasar Kebijakan (Jakarta: Kencana, 2007), 68. tersedia, hal ini membuat tingkat pengangguran di Indonesia semakin tinggi.

Suatu aspek dalam kinerja ekonomi adalah seberapa efektif suatu perekonomian menggunakan sumber daya dengan baik. Karena para pekerja suatu perekonomian adalah sumber daya utama, menjaga agar para pekerja tetap bekerja menjadi puncak perhatian para pembuat kebijakan ekonomi. Tingkat pengangguran adalah statistik yang mengukur presentase orang-orang yang ingin bekerja tetapi tidak mempunyai pekerjaan. $^{3}$

Menurut data yang di peroleh dari Badan Pusat Statistik (BPS), mulai tahun 2000 sampai dengan 2005 tingkat pengangguran di Indonesia mengalami kenaikan yang signifikan, yaitu pada angka 5,81 juta jiwa di tahun 2000 menjadi 11,37 juta jiwa pada tahun 2005. Tentunya tingkat pengangguran yang cukup tinggi ini menjadi beban pembangunan. Pemerintah menyadari hal itu, bahwa pengangguran yang tinggi akan memperlambat pertumbuhan ekonomi, maka dengan berbagai upaya diantaranya peningkatan kesempatan kerja melalui training atau pelatihan. ${ }^{4}$ Upaya dari pemerintah tersebut mulai memperoleh hasil, hal ini terlihat pada tingkat pengangguran di tahun 2008 yang menurun menjadi 9,41 juta jiwa.

Kemudian tingkat pengangguran mulai stabil pada tahun 2011 sampai dengan 2014, dengan rincian bahwa pada tahun 2011 pengangguran menurun menjadi 7,91 juta jiwa. Tahun 2012 menurun menjadi 7,42 juta jiwa, lalu tahun 2013 pengangguran menurun lagi menjadi 7,28. Dan kemudian di tahun 2014 turun menjadi 5,82 . Namun sayangnya pada bulan agustus tahun 2015 tingkat pengangguran di Indonesia kembali meningkat menjadi 2,56 juta jiwa.

$\mathrm{Ke}-6,34$

${ }^{3}$ N. Gregory Mankiw, Makroekonomi, Edisi

${ }^{4}$ Nur Feriyanto, Ekonomi Sumber Daya Manusia Dalam Perspektif Indonesia, 25. 
Pengangguran merupakan salah satu dari sekian banyak permasalahan ekonomi di Indonesia. Lalu, bagaimana Islam memandang pengangguran yang kini melanda negeri ini? Dalam Islam, manusia diciptakan di bumi ini untuk bekerja keras dan melarang mereka menganggur. Sebagai khalifah di bumi manusia diwajibkan berjuang mencari kejayaan hidup, untuk menanggulangi kesulitan hidup. ${ }^{5}$

Pada saat negara berkembang mencapai target pertumbuhan ekonomi namun tingkat kehidupan sebagian besar masyarakat umumnya tetap tidak berubah, maka hal ini menunjukan bahwa ada yang salah dengan pengertian pembangunan yang sempit. ${ }^{6}$ Sehingga yang menjadi fokus pembahasan pada penelitian ini yaitu tingkat pengangguran terbuka (mencari pekerjaan), dan seberapa besar pengaruh faktor-faktor inflasi, PDB, investasi, serta pendidikan dalam mempengaruhi tingkat pengangguran yang ada di Indonesia.

Masalah pengangguran sangat penting untuk dianalisa karena pengangguran dapat mengganggu stabilitas ekonomi di suatu daerah. Sebab, orang yang menganggur sudah jelas tidak memiliki penghasilan. Hal ini akan menimbulkan turunnya daya beli masyarakat terhadap barang maupun jasa.

Penelitian mengenai pengaruh inflasi, PDB, dan pertumbuhan ekonomi telah banyak dilakukan. Namun penelitian ini tetap dianggap penting karena dampak pengangguran terhadap suatu negara sangat besar.

Berdasarkan uraian di atas, maka penulis membatasi masalah dalam penelitian ini hanya sampai pada bagaimana pengaruh inflasi, PDB, investasi dan pendidikan terhadap tingkat pengangguran di Indonesia. Hal ini guna menghindari terjadinya tumpang tindih dengan masalah lain di luar

\footnotetext{
${ }^{5}$ Nurul Huda, at all, Ekonomi Makro Islam: Pendekatan Teoritis (Jakarta: Kencana Prenada Media Group, 2008), 228.

${ }^{6}$ Michael P. Todaro dan Stephen C. Smith, Pembangunan Ekonomi, Edisi Ke-11 Jilid 1 (Jakarta: Erlangga, 2011),17.
}

penelitian. Adapun beberapa pertanyaan yang diajukan, yaitu seberapa besar pengaruh inflasi terhadap tingkat pengangguran di Indonesia? Seberapa besar pengaruh PDB terhadap tingkat pengangguran di Indonesia? Seberapa besar pengaruh investasi terhadap tingkat pengangguran di Indonesia? Seberapa besar pengaruh pendidikan terhadap tingkat pengangguran di Indonesia? Seberapa besar pengaruh inflasi, PDB, investasi, dan pendidikan terhadap tingkat pengangguran di Indonesia?

\section{METODOLOGI PENELITIAN}

Wilayah kajian dalam penelitian ini adalah Ekonomi Pembangunan. Ekonomi pembangunan merupakan suatu bidang studi dalam ilmu ekonomi yang mempelajari tentang masalah ekonomi di negara berkembang dan kebijakan-kebijakan yang perlu dilakukan untuk mewujudkan pembangunan ekonomi. ${ }^{7}$ Masalah ekonomi pembangunan sangat berkaitan erat dengan ketenagakerjaan yang dalam hal ini untuk mengukur tingkat pengangguran yang menjadi salah satu tolak ukur kesejahteraan masyarakat dan pertumbuhan ekonomi suatu negara.

\section{Objek dan Waktu Penelitian}

Objek dalam penelitian ini yaitu tingkat pengangguran di Indonesia dari tahun 1999 sampai dengan tahun 2015. Penelitian ini akan dilaksanakan kurang lebih dua bulan sejak 8 Maret 2016 sampai dengan 8 Mei 2016. Penelitian tersebut akan dilakukan di Badan Pusat Statistik Kota Cirebon J1. Sekar Kemuning 1 Telp./Fax. (0231) 485524, 484403 - Cirebon 45135.

\section{Pendekatan Penelitian}

Pendekatan penelitian yang penulis gunakan adalah pendekatan kuantitatif dengan data yang digunakan yaitu data sekunder, yang diperoleh dari Badan Pusat Statistik (BPS)

${ }^{7}$ Sadono Sukirno, Ekonomi Pembangunan: Proses, Masalah, dan Dasar Kebijakan, 3. 
dan Bank Indonesia. Dalam hal ini, penulis meneliti mengenai tingkat pengangguran di Indonesia yang dipengaruhi oleh beberapa faktor yaitu inflasi, PDB, investasi dan pendidikan terhadap tingkat pengangguran di Indonesia.

Pendekatan kuantitatif disebut sebagai metode positivistic karena berlandaskan pada filsafat positivism. Metode ini sebagai metode ilmiah (scientific) karena telah memenuhi kaidah-kaidah ilmiah yaitu konkrit (empiris), obyektif, terukur, rasional, dan sistematis. ${ }^{8}$

Model penelitian yang digunakan untuk menganalisis data adalah model ekonometrika, serta metode yang digunakan adalah metode kuadrat terkecil (Ordinary Least Square) yang bertujuan untuk mengetahui seberapa besar pengaruh variabel independen terhadap variable dependen baik secara langsung maupun secara tidak langsung. Untuk menganalisis data menggunakan bantuan program SPSS versi 17.

\section{Data dan Sumber Data}

Data diartikan sebagai sesuatu yang diketahui atau dianggap dapat memberikan gambaran tentang suatu keadaan atau persoalan yang dikaitkan dengan waktu dan tempat, serta dapat digunakan untuk mengambil keputusan oleh para pembuat keputusan (decision makers). ${ }^{9}$ Jenis data yang penulis gunakan adalah jenis data sekunder. Data Sekunder adalah data yang memberikan penjelasan mengenai bahan primer ${ }^{10}$. Dalam arti lain data sekunder ialah data yang telah disediakan oleh pihak lain (sudah tersedia).

Sumber data yang dimaksud sumber data dalam penelitian adalah subjek dari

\footnotetext{
${ }^{8}$ Sugiyono, Metode Penelitian Kuantitatif, Kualitatif, dan $R \& D$ (Bandung: Alfabeta, 2012), 7.

${ }^{9}$ Kusmayadi, Statistika Pariwisata Deskriptif (Jakarta: PT Gramedia Pustaka Utama, 2004), 46.

${ }^{10}$ Bambang Sunggono, Metode Penelitian Hukum (Jakarta: PT Raja Grafindo Persada, 2003), 4.
}

mana data dapat diperoleh ${ }^{11}$. Pada penelitian ini, peneliti menggunkan sumber data yang diperoleh dari Badan Pusat Statistik (BPS).

\section{KAJIAN PUSTAKA Pengangguran}

Pengangguran merupakan masalah ketenagakerjaan yang dialami oleh banyak negara. Begitu seriusnya masalah ini sehingga dalam setiap rencana-rencana pembangunan ekonomi masyarakat selalu dikatakan dengan tujuan untuk menurunkan angka pengangguran. Namun kebijaksanaan pemecahan sudah barang tentu harus dialamatkan kepada apa yang menjadi penyebabnya. $^{12}$

Pengangguran adalah seseorang atau sekelompok orang yang termasuk angkatan kerja yang tidak dapat bekerja dan sedang mencari pekerjaan menurut referensi tertentu. ${ }^{13}$ Menganggur (unemployed) merupakan orang-orang yang tidak bekerja akan tetapi secara aktif sedang mencari pekerjaan atau orang-orang yang sedang menunggu untuk kembali bekerja.

Orang-orang yang mempunyai pekerjaan adalah tergolong bekerja, namun bagi orang-orang yang tidak mempunyai pekerjaan akan tetapi sedang dalam usaha mencari pekerjaan tergolong pengangguran. Adapun bagi orang-orang yang tidak mempunyai pekerjaan tetapi tidak bermaksud untuk mencari pekerjaan, maka tidak dimasukan ke dalam angkatan kerja. Tingkat pengangguran dihitung dari jumlah orang yang menganggur dibagi dengan seluruh angkatan kerja. ${ }^{14}$

\footnotetext{
${ }^{11}$ Suharsini Arikunto, Prosedur Penelitian Suatu Pendekatan Praktik (Jakarta: Rieneka Cipta, 2006), 129.

${ }^{12}$ Sonny Sumarsono, Teori dan Kebijakan Publik Ekonomi Sumber Daya Manusia (Yogyakarta: Graha Ilmu, 2009), 249.

${ }^{13}$ Nur Feriyanto, Ekonomi Sumber Daya Manusia Dalam Perspektif Indonesia, 159.

${ }^{14}$ Paul A. Samuelson dan William D. Nordhaus, Makroekonomi, Edisi Ke-14 (Jakarta: Erlangga, 1992), 291.
} 
Dari beberapa pendapat di atas, maka penulis mengambil kesimpulan bahwa pengangguran adalah seseorang atau sekelompok orang yang termasuk angkatan kerja, tetapi tidak mempunyai pekerjaan namun sedang aktif mencari pekerjaan.

\section{Jenis Pengangguran Berdasarkan Penyebabnya}

1. Pengangguran Friksional

Terjemahan luas dari kata frictional adalah gesekan. Jadi pengangguran riksional adalah pengangguran yang di sebabkan oleh suatu hambatan yang menyebabkan proses bertemunya penawaran dan permintaan tenaga kerja menjadi titik lancar. ${ }^{15}$ Pengangguran friksional terjadi karena berpindahnya orang-orang dari satu daerah ke daerah lain, dan dari satu jenis pekerjaan kepekerjaan lain atau melalui berbagai tingkat siklus kehidupan yang berbeda. ${ }^{16}$

Pengangguran friksional merupakan pengangguran yang terjadi karena kesulitan temporer dalam mempertemukan pencari kerja dan lowongan kerja yang ada. Kesulitan temporer ini dapat berbentuk tenaga waktu yang diperlukan selama proses atau prosedur pelamaran dan seleksi, atau terjadi karena faktor jarak atau kurangnya komunikasi. Kesulitan temporer juga dapat terjadi karena kurangnya mobilitas pencari kerja dimana lowongan pekerjaan justru terdapat bukan disekitar tempat tinggal si pencari kerja. Misalnya, pencari kerja berkumpul di Cirebon sedangkan lowongan pekerjaan terdapat di Jakarta. Selain itu kesulitan temporer dapat terjadi jika si pencari kerja tidak mengetahui dimana adanya lowongan pekerjaan dan demikian pula pengusaha tidak mengetahui dimana tersedianya tenaga- tenaga yang sesuai. ${ }^{17}$

\footnotetext{
${ }^{15}$ Sonny Sumarsono, Teori dan Kebijakan Publik Ekonomi Sumber Daya Manusia (Yogyakarta: Graha Ilmu, 2009), 251.

${ }^{16}$ Paul A. Samuelson dan William D. Nordhaus, Makroekonomi, Edisi Ke-14, 292.

${ }^{17}$ Sonny Sumarsono, Teori dan Kebijakan Publik Ekonomi Sumber Daya Manusia, 251.
}

2. Pengangguran Siklikal

Pengangguran siklis terjadi apabila permintaan tenagakerja secara keseluruhan rendah. Apabila total pembelanjaan dan output menurun, maka pengangguran akan meningkat dengan segera disegala bidang. ${ }^{18}$ Pada masa ekspansi orang biasanya penuh dengan optimis, dalam situasi seperti ini maka dampak terhadap kesempatan kerja menjadi positif. Kenaikan permintaan tenaga kerja akan mengurangi pengangguran. Sebaliknya jika seseorang sudah kehilangan kepercayaan terhadap peluang di masa depan, sikap pesimisme yang timbul seperti ini membawa dampak negatif pada kesempatan kerja. Hal ini terekam oleh naiknya tingkat pengangguran, pengangguran yang berirama seperti ini disebut pengangguran siklikal yang terjadi sesuai dengan konjuktur atau Business Cycles yang dapat tejadi 5 (lima) tahun sekali. ${ }^{19}$

\section{Pengangguran Struktural}

Pengangguran struktural adalah pengangguran yang terjadi karena perubahan dalam struktur atau komposisi perekonomian. Perubahan struktur yang demikian memerlukan perubahan dalam keterampilan tenaga kerja yang dibutuhkan, sedangkan pihak pencari kerja tidak mampu menyesuaikan diri dengan keterampilan baru tersebut. Hal ini terjadi karena dampak dari kemajuan ekonomi yang menyebabkan terjadinya perubahan dominasi peranan ekonomi yang dimainkan oleh setiap sektor dalam kegiatan produksi maupun dalam pemberian kesempatan kerja. ${ }^{20}$

Penganggura struktural menunjukan terjadinya ketidaksesuaian antara penawaran dan permintaan tenaga kerja. Ketidaksesuaian ini terjadi karena permintaan atas satu jenis pekerjaan

${ }^{18}$ Paul A. Samuelson dan William D. Nordhaus, Makroekonomi, Edisi Ke-14, 292.

${ }^{19}$ Sonny Sumarsono, Teori dan Kebijakan Publik Ekonomi Sumber Daya Manusia, 252.

${ }^{20}$ Sonny Sumarsono, Teori dan Kebijakan Publik Ekonomi Sumber Daya Manusia, 252. 
bertambah sementara permintaan akan jenis pekerjaan lain menurun dan penawaran tidak dapat melakukan penyesuaian dengan cepat atas situasi tersebut. ${ }^{21}$

\section{Pengangguran Teknologi}

Dalam pertumbuhan industri kita amati bahwa teknologi yang dipakai dalam proses produksi selalu berubah. Ternyata laju pertumbuhan itu semakin hari semakin cepat, diberbagai industri elektronika. Perubahan teknologi merupakan bagian yang tidak dapat dipisahkan dari kehidupan sehari-hari. Perubahan teknologi produksi membawa dampak kesempatan kerja ke berbagai arah. Kekuatan substitutif dan kekuatan merombak spesifikasi jabatan yang ditimbulkan membawa dampak negatif bagi kesempatan kerja berupa pengangguran. $^{22}$

\section{Inflasi}

Inflasi didefinisikan sebagai suatu proses kenaikan harga-harga yang berlaku dalam suatu perekonomian. ${ }^{23}$ Inflasi timbul tidak disebabkan oleh satu hal saja, inflasi timbul karena berbagai alasan. Sebagian inflasi timbul dari sisi permintaan, sebagian lainnya dari sisi penawaran. ${ }^{24}$

Sedangkan menurut Rahardja dan manurung mengatakan bahwa, inflasi adalah gejala kenaikan barang-barang yang bersifat umum dan terus menerus dari suatu perekonomian. $^{25}$

Secara umum inflasi berarti kenaikan tingkat harga secara umum dari barang/komoditas dan jasa selama periode waktu tertentu. Inflasi dapat dianggap

\footnotetext{
${ }^{21}$ Paul A. Samuelson dan William D. Nordhaus, Makroekonomi, Edisi Ke-14, 292.

${ }^{22}$ Sonny Sumarsono, Teori dan Kebijakan Publik Ekonomi Sumber Daya Manusia, 253.

${ }^{23}$ Sadono Sukirno, Makroekonomi Teori Pengantar (Jakarta: PT. Raja Grafindo Persada, 2006), 14.

${ }^{24}$ Paul A. Samuelson, William D. Nordhaus, Makroekonomi, Edisi Ke-14, 323.

${ }^{25}$ Nurul Huda, at all, Ekonomi Makro Islam: Pendekatan Teoritis, 175.
}

sebagai fenomena moneter karena terjadinya penurunan nilai unit penghitungan moneter terhadap suatu komoditas. ${ }^{26}$

\section{Faktor Penyebab Inflasi}

Terdapat bebrapa faktor yang dapat menyebabkan terjadinya inflasi, ${ }^{27}$ diantaranya yaitu sebagai berikut:

1. Tingkat Pengeluaran Agregat yang Melebihi Kemampuan Perusahaan untuk Menghasilkan Barang dan Jasa.

Tingkat pengeluaran agregat adalah pengeluaran keseluruhan perusahaan. Apabila pengeluaran total perusahaan melebihi kemampuannya dalam menghasilkan barang dan jasa, tentunya akan memicu kenaikan harga barang dan jasa yang dihasilkan tersebut.

\section{Tuntutan Kenaikan Upah dari} Pekerja.

Seringkali pekerja atau karyawan perusahaan melakukan demo menuntut kenaikan upah. Adanya kenaikan upah karyawan akan menyebabkan biaya produksi barang dan jasa juga meningkat dan pada akhirnya akan meningkatkan harga barang dan jasa tersebut.

3. Kenaikan Harga Barang Impor.

Kenaikan harga barang impor tentu akan dapat membawa pengaruh terhadap kenaikan harga dalam negeri, terlebih lagi jika barang impor tersebut merupakan bahan mentah untuk memproduksi suatu barang dalam negeri.

\section{Penambahan Penawaran Uang} dengan Cara Mencetak Uang Baru.

Apabila jumlah uang yang beredar di masyarakat banyak, maka nilai uang pada suatu barang akan turun, yang akhirnya

${ }^{26}$ Adiwarman A. Karim, Ekonomi Makro Islam (Jakarta: PT. Raja Grafindo Persada, 2013), 135.

${ }^{27}$ http://www.pendidikanekonomi.com/2014/0 7/inflasi-dan-faktor-penyebabnya.html?m=1. Diakses pada tanggal 27 Maret 2016. 
menyebabkan kenaikan pada barang dan jasa.

5. Kekacauan Politik dan Ekonomi.

Hal ini pernah terjadi di Indonesia, yatiu pada tahun 1998. Akibat kekacauan politik dan ekonomi tahun 1998, angka inflasi di Indonesia mencapai 70\%.

\section{Produk Domestik Bruto (PDB)}

Secara sederhana pendapatan nasional dapat diartikan sebagai jumlah barang dan jasa yang dihasilkan suatu negara pada periode tertentu biasanya satu tahun. Istilah yang terkait dengan pendapatan nasional sangat beragam antara lain, produk domestik bruto (gross domestic product/GDP), produk nasional bruto (gross national product) GNP), serta produk nasional neto (Net National Product/ NNP).$^{28}$ Produk domestik bruto (PDB) adalah nilai pasar semua barang dan jasa akhir yang diproduksi dalam perekonomian selama kurun waktu tertentu. ${ }^{29}$ PDB merupakan ukuran pokok dari kegiatan ekonomi. ${ }^{30}$

\section{Investasi}

Kata investasi merupakan kata adopsi dari bahasa Inggris, yaitu investment. Kata invest sebagai kata dasar dari investment memiliki arti menanam. Dalam Webster's New Collegiate Dictionary, kata invest didefinisikan sebagai to make use of for future benefits or advantages and to commit (money) in order to earn a finanfial return. Selanjutnya, kata investment diartikan sebagai the outley of money use for income or profit.

Dalam kamus istilah pasar modal dan kuangan kata investasi diartikan sebagai penanaman uang atau modal dalam suatu perusahaan atau proyek untuk tujuan

\footnotetext{
${ }^{28}$ Nurul Huda, at all, Ekonomi Makro Islam: Pendekatan Teoritis, 21.

${ }^{29}$ N. Gregory Mankiw, Makroekonomi, Edisi ke 6, 19.

${ }^{30}$ Rudiger Dornbusch dan Stanley Discher, Makroekonomi, Edisi Ke 4 (Jakarta: Erlangga, 1990), 5.
}

memperoleh keuntungan. Dan dalam Kamus Lengkap Ekonomi, investasi didefinisikan sebagai pertukaran uang dengan bentukbentuk kekayaan lain seperti saham atau harta tidak bergerak yang diharapkan dapat ditahan selama periode waktu tertentu supaya menghasilkan pendapatan. ${ }^{31}$

Penanaman modal atau investasi merupakan langkah awal kegiatan prodiksi. Pada posisi ini, investasi merupakan awal kegiatan pembangunan ekonomi. Penanaman modal mempengarui tinggi rendahnya pertumbuhan ekonomi dan mencerminkan bergairah atau lesunya perekonomian suatu negara. Dalam mempercepat pembangunan ekonomi diperlukan peningkatan penanaman modal untuk mengolah potensi ekonomi menjadi kekuatan ekonomi riil dengan menggunakan modal yang berasal dari dalam negeri maupun dari luar negeri. Disamping menggali sumber pemniayaan asli daerah, pemerintah daerah juga mengundang sumber pembiayaan luar negeri salah satunya adalah penanaman modal asing. ${ }^{32}$

\section{Pendidikan}

Pendidikan adalah input (masukan) bagi fungsi produksi nasional dalam perannya sebagai komponen modal manusia (human capital), yang berarti investasi produktif dalam sumber daya manusia. Peningkatan pendidikan merupakan tujuan tersendiri yang penting dari upaya pembangunan. Kita tidak dapat dengan mudah menyatakan bahwa suatu negara dengan penduduk berpendapatan tinggi namun tidak terdidik dengan baik dan mengalami masalah kesehatan yang signifikan sehingga masa hidup mereka jauh lebih singkat dibanding orang-orang dimuka bumi yang telah

\footnotetext{
${ }^{31}$ Nurul Huda dan Mustafa Edwin Nasution, Invetasi Pada Pasar Modal Syariah (Jakarta: Kencana Prenada Media Group, 2008), 7.

${ }^{32}$ Rendy Sagita, "Analisis Kausalitas Infrastruktur dengan Investasi Asing untuk Meningkatkan Produk Domestik Bruto (PDB) Indonesia", Economics Development Analysis Journal, Vol. 2, No. 4 (Juni, 2013): 298.
} 
mencapai tingkat pembangunan yang lebih tinggi disbanding dengan negara berpendapatan rendah dengan tingkat harapan hidup penduduknya yang lebih tinggi dan sebagian besar melek aksara.

Dengan demikian, indikator yang kebih baik untuk menunjukan perbedaan dan peringkat pencapaian pembangunan adalah dengan memasukan variabel pendidikan dalam ukuran kesejahteraan tertimbang (weighted wellbeing measure). ${ }^{33}$

\section{PENGARUH INFLASI TERHADAP TINGKAT PENGANGGURAN}

Berdasarkan hasil penelitian, inflasi secara signifikan dan positif mempengaruhi tingkat pengangguran di Indonesia. Adapun hubungan positif maupun negatif inflasi terhadap tingkat pengangguran yang terjadi. Apabila tingkat inflasi yang dihitung adalah inflasi yang terjadi pada harga-harga secara umum, maka tingginya tingkat inflasi akan berakibat terhadap peningkatan tingkat bunga atau pinjaman. Oleh karena itu, dengan tingkat bunga yang tinggi dapat mengurangi investasi untuk mengembangkan sektor-sektor yang produktif.

Meurut J. M. Keyness, hubungan antara variabel moneter dengan variabel riil sangat kuat. Modelklasik menyatakan bahwa harga termasuk upah ditentukan oleh mekanisme pasar dan penyesuaian upah nominal tidak ada pada periode tertentu. Model Keynessian menyatakan bahwa keungkinan kuantitas penawaran dan perminataan tenaga kerja tidak sama dengan kemungkinan yang sering terjadi adalah kelebihan penawaran tenaga kerja. Hubungan antara tingkat harga dan tingkat pengangguran dijelaskan oleh Kurva Phillips.

\footnotetext{
${ }^{33}$ Michael P. Todaro dan Stephen C. Smith, Pembangunan Ekonomi, Edisi Ke-11 Jilid, 60.
}

\section{PENGARUH PDB TERHADAP TINGKAT PENGANGGURAN}

Produk Domestik Bruto (PDB) berpengaruh negatif dan signifikan terhadap tingkat pengangguran. Konsep yang mempelajari hubungan PDB dan tingkat pengangguran dikenal dengan hukum okun yang dikemukakan oleh ekonom bernama Arthur Okun. Hukum Okun menjelaskan bahwa PDB memiliki pengaruh negatif terhadap tingkat pengangguran. Hubungan antara PDB dan tingkat pengangguran dapat diformulasikan sebagai berikut: ${ }^{34}$

$$
\frac{\Delta Y}{Y}=3 \%-2 x \Delta u
$$

Notasi $\Delta \mathrm{Y} / \mathrm{Y}$ menyatakan perubahan PDB, sedangkan notasi $\Delta \mathrm{u}$ menyatakan perubahan tingkat pengangguran. Dari pernyataan hukum Okun tersebut diketahui bahwa tingkat pengangguran berkorelasi negatif dengan pertumbuhan PDB. Hal ini menjelaskan, jika PDB mengalami kenaikan, maka tingkat pengangguran akan turun.

\section{PENGARUH INVESTASI TERHADAP TINGKAT PENGANGGURAN}

Dalam penelitian ini, secara individual investasi berpengaruh negatif terhadap tingkat pengangguran. Hal ini sesuai dengan teori Harrod Domar (Mulyadi, 2003), yang dalam teorinya berpendapat bahwa investasi tidak hanya menciptakan permintaan, tetapi juga memperbesar kapasitas produksi. Artinya dengan semakin besar kapasitas produksi maka akan membutuhkan banyak tenaga kerja pula. Selain itu juga sesuai dengan Afrida (2003), yang menyatakan bahwa pengeluaran investasi memberikan peluang untuk tumbuhnya kesempatan kerja, bila permintaan terhadap barang dan jasa rendah, maka akan timbul pula kelemahan pada permintaan tenaga kerja.

Sebagian ahli ekonomi memandang bahwa pembentukan investasi merupakan

\footnotetext{
${ }^{34}$ https://arda.biz/ekonomi/ekonomimakro/pengaruh-pertumbuhan-ekonomi-terhadappengangguran/. Diakses pada 17 Juni 2016.
} 
faktor penting yang bertanggung jawab terhadap pertumbuhan dan pembangunan ekonomi suatu negara.ketika perusahaan atau individu maupun pemerintah melakukan investasi, maka ada sejumlah modal yang ditanam atau dikeluarkan, atau ada sejumlah pembelian barang-barang yang tidak dikonsumsi, tetapi digunakan untuk produksi, sehingga menghasilkan barang dan jasa di masa yang akan datang. Suatu negara akan berkembang secara dinamis jika investasi yang dikeluarkan jauh lebih besar dari pada nilai penyusutan faktor produksinya akan cenderung mengalami perekonomian yang stagnasi.

\section{PENGARUH \\ TERHADAP \\ PENGANGGURAN}

PENDIDIKAN TINGKAT

Dari hasil penelitian yang dilakukan dengan variabel dummy terhadap pendidikan secara keseluruhan pendidikan berpengaruh negatif dan signifikan terhadap tingkat pengangguran. Hal ini sesuai dengan teori human capital dimana seseorang dapat meningkatkan penghasilannya melalui peningkatan pendidikan. Setiap tambahan satu tahun sekolah berarti, disatu pihak, meningkatkan kemampuan kerja dan tingkat penghasilan selama satu tahun dalam mengikuti sekolah tersebut.

Namun, pada variabel dummy SMP/MTs menunjukan adanya kenaikan positif antara tingkat pendidikan dengan tingkat pengangguran. Ini berarti adanya ketidakseimbangan teori human capital dengan hasil analisis data meskipun tingkat pendidikan mempengaruhi tingkat pengangguran. Hal ini disebabkan membludaknya jumlah lulusan SMP/MTs yang tidak diimbangi dengan kesempatan kerja yang ada.

Dan tingkat pendidikan yang tinggi cenderung mencari pekerjaan di daerah leading sector sesuai dengan pendidikannya, karena hal ini akan lebih leluasa bersaing di daerah atau provinsi lain yang leading sector usaha sesuai dengan pendidikan yang dimiliki seorang tersebut.
Dalam penelitian ini, secara individual tingkat pendidika pada perguruan tinggi tidak berpengaruh terhadap tingkat pengangguran. Hal ini bisa terjadi karena dari data diperoleh jumlah orang yang menyelesaikan pendidikan pada perguruan tinggi menempati posisi terendah dibanding yang lainnya, artinya tidak banyak masyarakat Indonesia yang mengenyam pendidikan sampai pada perguruan tinggi dan dengan demikian besar kecilnya tingkat lulusan perguruan tinggi tidak memengaruhi tingkat pengangguran. Artinya, besar juga kesempatan kerja bagi lulusan perguruan tinggi.

\section{KESIMPULAN}

Berdasarkan hasil penelitian dan pembahasan yang telah dilakukan dapat ditarik 4 (empat) kesimpulan dari penelitian pengaruh inflasi, PBD, investasi dan pendidikan terhadap tingkat pengangguran, sebagai berikut:

Pertama, inflasi berpengaruh negatif dan signifikan terhadap tingkat pengangguran sebesar 3.317. Artinya setiap kenaikan inflasi akan menaikan tingkat pengangguran di Indonesia. Kedua, produk Domestik Bruto (PDB) berpengaruh negatif dan signifikan terhadap tingkat pengangguran sebesar -4.788. Maka setiap kenaikan PDB, mengurangi tingkat pengangguran di Indonesia. Ketiga, investasi berpengaruh negatif dan signifikan terhadap tingkat pengangguran sebesar 2.396. Artinya dari setiap kenaikan angkat investasi, maka akan mengurangi tingkat pengangguran di Indonesia.

Dan keempat, pendidikan berdasarkan perhitungan variabel dummy pada tingkat SD/MI berpengaruh negatif dan signifikan terhadap tingkat pengangguran sebesar -4.542. Pada tingkat SMP/MTs berpengaruh positif dan signifikan terhadap tingkat pengangguran sebesar 9.305.Tingkat SMA/MA berpengaruh negatif dan signifikan terhadap tingkat pengangguran sebesar -4.373. Sedangkan pada tingkat pendidikan perguruan tinggi tidak terdapat 
pengaruh terhadap tingkat pengangguran. Inflasi, PDB, investasi dan pendidikan memengaruhi secara parsial terhadap tingkat pengangguran di Indonesia sebesar $93.2 \%$.

\section{DAFTAR PUSTAKA}

Arikunto, Suharsini. Prosedur Penelitian Suatu Pendekatan Praktik. Jakarta: Rieneka Cipta, 2006.

Dornbusch, Rudiger dan Stanley Discher. Makroekonomi, Edisi Ke-4. Jakarta: Erlangga, 1990.

Feriyanto, Nur. Ekonomi Sumber Daya Manusia Dalam Perspektif Indonesia. Yogyakarta: UPP STIM YKPN, 2014.

https://arda.biz/ekonomi/ekonomimakro/pengaruh-pertumbuhanekonomi-terhadap-pengangguran/.

Huda, Nurul at all. Ekonomi Makro Islam: Pendekatan Teoritis. Jakarta: Kencana Prenada Media Group, 2008.

Huda, Nurul dan Handi Risza Idris, at all. Ekonomi Makro Islam Pendekatan Teoritis. Jakarta: Kencana Prenada Media Group, 2009.

Huda, Nurul dan Mustafa Edwin Nasution. Invetasi Pada Pasar Modal Syariah. Jakarta: Kencana Prenada Media Group, 2008.

Karim, Adiwarman A. Ekonomi Makro Islam. Jakarta: PT. Raja Grafindo Persada, 2013.

Kusmayadi. Statistika Pariwisata Deskriptif. Jakarta: PT Gramedia Pustaka Utama, 2004.

Mankiw, N. Gregory. Makroekonomi, Edisi Ke-6. Jakarta: Erlangga, 2006.

Samuelson, Paul A. dan William D. Nordhaus. Makroekonomi, Edisi Ke14 (Jakarta: Erlangga, 1992.

Sugiyono. Metode Penelitian Kuantitatif, Kualitatif, dan $R$ \& D. Bandung: Alfabeta, 2012.

Sukirno, Sadono. Ekonomi Pembangunan: Proses, Masalah, dan Dasar Kebijakan. Jakarta: Kencana, 2007.

Sukirno, Sadono. Makroekonomi Teori Pengantar. Jakarta: PT. Raja Grafindo Persada, 2006.
Sumarsono, Sonny. Teori dan Kebijakan Publik Ekonomi Sumber Daya Manusia. Yogyakarta: Graha Ilmu, 2009.

Sunggono, Bambang. Metode Penelitian Hukum. Jakarta: PT Raja Grafindo Persada, 2003.

Todaro, Michael P. dan Stephen C. Smith. Pembangunan Ekonomi, Edisi Ke-11 Jilid 1. Jakarta: Erlangga, 2011. 